\title{
Production technology designed for heavy oil recovery of a marginal field offshore Vietnam
}

- Vu Viet Hung

- Tran Thai Son

Lam Son Joint Operating Company

(Manuscript Received on August 10 ${ }^{\text {th }}$, 2015; Manuscript Revised on October 20 ${ }^{\text {th }}$, 2015)

\begin{abstract}
Production technology application in heavy oil production has been widely developed in industry over past decades in an effort to improve the ultimate recovery of this "difficult" hydrocarbon. Apart from thermal method, pumping technology makes remarkable advance by enlarging the draw-down created over the conventional gas-lift in several heavy oil projects. This paper presents the production technology design set out in the Field Development Plan (FDP) to enhance the wellbore lifting efficiency of a marginal heavy oil field offshore Vietnam. The finding of $20^{\circ} \mathrm{API}$ viscous oil in Cии Long Basin is weird to the geologist and its considerable large reserve

development strategy to efficiently and economically extract this reserve. In so doing, a series of systematic technical studies has been purposely planned from the first encounter of heavy oil in wildcat well to the modelling study and asset design to accommodate the viscous fluid whilst optimizing the economic yield over the field life. Among them, the application of Electric Submersible Pump (ESP) was finally decided as the key driver to reinforce the well performance. As a result, the facility design at the surface such as surface electrical system coupledwith gas-lift back-up, sand control, chemical injection and so on, all integrated in one to boost production and prolong well life.
\end{abstract} challenges operator in thinking of a suitable

Key words: Electric Submersible Pump, heavy oil, recovery, combination, back-up

\section{INTRODUCTION}

The application of the ESP has been wellknown in the industry but still quite low in Vietnam. Whilst a neighbour field employed it since early two thousands as an alternative in the event gas-lift system unavailability, the application in this project is to enhance artificial lift efficiency in heavy oil production. It's a long progress from the very first few days when encountered viscous oil in the well testing to the concept selection, equipment sizing, deployment considerationand economic aspect. This paper introduces a systematic approach todesign an efficient artificial lift system to enhance production of the heavy oil reservoir, Tay Do 
field from the field development planning to execution phase.

\section{Background}

The Tay Do field was found commercially via threewildcat wells with wide range of formation and fluid properties. Its development concept is depicted in Figure 1 in which heavy oil producers in Platform B will be the candidate for artificial lift optimization.

Three pay zones were discovered in the Middle Miocene Upper-Lower Con Son formations (BII.2.20, BII.2.30 and BII.1.10) in wildcat wellsA, B and C as stacked channel sandstones trapped. Each gross sandstone package is about $30-40 \mathrm{~m}$ thick, capped above by $10-30 \mathrm{~m}$ ofshale/clay stones. The vertical cross section over the wildcat wells is illustrated in figure 2 .

The diverse in fluid properties $\left(20.5^{0} \mathrm{API}\right.$ to $35^{\circ} \mathrm{API}$ ) posed difficulty in selecting production technology method to enhance wellbore lifting efficiency.

Question was raised during the FDP in how to develop them concurrently with regards to reservoir management perspective. Drilling highly deviated well with single completion string and artificial lift to produce from only one formation is a preferable concept in this marginal field development.

\section{PRODUCTION TECHNOLOGY SCREENING}

\footnotetext{
Contribution to the complexity includesvarious production technologies forenhanced recovery of a marginal field andthe existence ofthe corrosion agents in the well stream. The screening exercise aimed at the following purposes.

- Improve the overall lifting efficiency of the wells.
}

- Gas-lift becomes fairly inefficient with heavy oil.

- Accelerate production by applying more aggressive pressure drawdown.

- High fluid production rate compensates oil reduction as a result of water cut increasing.

- Available deployment technologies and economic/technical comparison.

- Reservoir development and production forecasts.

The reservoir data shown in Table 1 coupled with detailed pros/cons of each artificial lift method outlined in Table 2 provide a snapshot for consideration. A quick check between ESP and gas-lift was carried out in reservoir simulationgiven the same operating condition. It turned out that ESP outperformed gas-lift in lowering bottom-hole flowing pressure which resulted in about $30 \%$ incremental recovery.

Viscous fluid with almost no solution gas and shallow depth best suits to the ESP or Progressive Cavity Pump (PCP). The major concern in those options is the solid production as a nature of shallow and unconsolidated reservoir which will definitely lead to the shortage of run life. Therefore, a rigorous geomechanic and sand production study were performed beforehand to ensure sand-free fluid flow in the wellbore. Besides, high production rate and the population in the area make ESP a bit advance than its counterpart.

After due consideration, the ESP is selected to proceed to detailed engineering studywith facility team and pump vendors.

\subsection{ESP Design Consideration}

The optimization scheme to account for reservoir parameter changes, involve the selection of pump curve type that would have less impact with the potential changes in these parameters. In addition, the number of stages is 
selected to have enough to absorb the total change in total dynamic head.

In the first step, a model for a typical Well $\mathrm{X}$ was built and validated with the existing gaslift data as shown in Figure 4. The design for Well X was based these following assumptions:

- Static Bottom Hole Pressure: 2061 psi @ 1490 mTVD

- Anticipated Productivity Index: 3.3 bbls/psi (from Pressure Build Up interpretation)

- Anticipated Reservoir Temperature: $171^{0} \mathrm{~F}$

- Pump degraded 5\%-15\% with the increasing of viscosity and impurity gas $\mathrm{H}_{2} \mathrm{~S}$ which was found quite substantial in the well testing.

The GOR of the candidate wells is quite low (approx. 10scf/stb) and the intake pressure into the ESPs are far above the bubble point (approx. 100 psi). Therefore, intake gas separation is not recommended here. In reality, due to lots of limitation, only one compromised solution which give the best efficiency with respect to wide range of well performance, is considered.

According to the designed operating conditions, the ESP system has been designed to be operating with a pump intake pressure of 1,396 psig. $0 \%$ of free gas will enter the pump, allowing operation without the installation of a gas separator.

Selection of the ESP system was based on surfacefacilityconstraint on $65 \mathrm{KW}$ power consumption and production rate 1,500 BLPD. Other variables were assumed when not given and all of these conditions should be analysed again when final data is available in order to ensure proper equipment selection.

The pump designed for Well $\mathrm{X}$ is summarized in Table 3. The total power consumption is $66 \mathrm{KVA}$ or $56 \mathrm{KW}$, including loss through downhole cable.All of the selected equipments will utilize Abrasion Resistant (AR) components and Corrosive Resistance material. The 3 chambers seal, L/2BP, which contains 3 mechanical seals have been chosen. The pump curve and inflow/outflow performance are shown in Figure 6 and Figure 7respectively.

The optimized configuration recommended in this operating condition is thecompletion illustrated in Figure 5 - Conventional ESP without tailpipe.

Since the pump will have the full clearance within the 9-5/8" casing it is comfortablewith the installation and operation under these conditions. The clearance is sufficient toconsider shrouds on these two wells to ensure the pump motors are sufficiently cooled.

\subsection{ESP Deployment Methods}

The jointed pipe ESPs are the industry standard in ESP completion whilst a recently developed technology, so-called "spoolable completion", refers to a method where the string can be run and/or pulledrapidly without need for a rig.Generallydeployed via coiled tubing (CT), these configurations can provide operational savings due to their speed of workover and elimination of rig costs in favour of CT units. Table 4 outlines the two ESP completion methods where the jointed pipe completion is split to rig and Hydraulic Workover Unit-based.

In evaluating spoolable completions for use on the specifics of the wells andplatform itself must also be reviewed:

- Platform B on which the candidate wellheads are located has very little additional room for equipment. At minimum, during a CT workover, space would be required for the CT unit, reel, and power pack. In addition, there is a limitation on the crane and its capability to handle such kit. 
- The preferred option available would be to perform all operations from a barge. This has been done previously on other projects overseas, however, safety precautions would need to be taken to ensure that disconnect could be executed in the event of torrential weather.

- The disadvantages of thattechnique including well control issues at the surface andconcern regarding security of the cable; it provides even less production due to the associated friction losses ofannular flow between the $\mathrm{CT}$ and casing.

- The other issue with this method is that it does not provide access to the producing zones below the ESP and gas-lift backup.

The industry standard method does require a rig or HWU to workover the well should the ESP malfunction.It is costly operation but enjoy the simple completion scheme and low CAPEX. Alternatively, it is highly recommended to install contingency gas lift mandrels (Figure 8) which could be used to continue production whilst awaiting mobilization.

An economic analysis is also performed to further evaluate CT ESPs vs.Jointed Pipe ESPs with rig support as well as HWU support.

A summary table (Table 5) lists the various options withtheir simulated incremental oil (vs. current gas lift). This includes any differences due tolead time for equipment, lead times for rig and CT unit mobilization but not the production from gas-lift when the pump failure.

Aside from the above technical comparison, this economic analysis does show that CT deployed ESP does provide the best net undiscounted return vs. the jointed pipeESPs $(\$ 12.7 \mathrm{MM})$. The main differences are the incremental oil attributed to less workover time, the service rate and original CAPEX. Technically the CT deployed ESP required extensive platform upgrade which will impact to overall project schedule and hidden cost during construction.

Based on the analysis contained herein (both technical and economic) we haverecommended to install an ESP on jointed pipe below a retrievable packer. Above the

ESP would be installed gas lift mandrels as a contingency lift method should there be arequirement to retrieve and replace the pump. The concept considers a primary system such as ESP combined with gas-lift as secondary system.

The application of combined artificial lift systems yields improved production in terms of costs and rates at better conditions than could be expected from using only one of the individual systems. The combination provides a wide operating range reaching the optimal technical and economical performance. The long-term benefits are a reduction in production downtime.

The analysis clearly leads to recommend jointed pipe as the choice forthis project. It has benefits in its simplicity, economic efficiency and ability to withstand thewell profile. The other methods described herein have strong advantages but are simplycompromised technically due to critical project schedule.

\subsection{Challenging}

Pilot application always comes with risk and uncertainty regarding installation, maintenance and performance optimization in long run. Key remarks include:

- Performance Data Availability: ESP calibration based on gas-lift data.

- Offshore people expertise and skill shortage.

- Power source stability

- Full bypass for wireline and hydraulic access below ESP.

- Chemical injection for continuous $\mathrm{H}_{2} \mathrm{~S}$ scavenger/viscosity reduction below the pump. 


\section{CONCLUSION}

Marginal fields requires cost-effective and high efficiency concepts to maximize revenues and make the project economics.

- Studying reservoir performance is essential to understand the specifics of the flow dynamics to assist concept selection.

- Potential changes in ESP design parameters and consequences of reservoir performance effect during production.
- Conventional ESP deployment with rig support is the robust option with the option of starting Gas-lift during pump failure.

- Dedicated system approach and good project management to overcome the challenges.

Acknowledgement: The authors gratefully acknowledge Dan Saenz (Schlumberger Representative in Bokor Project) and MiorYusni $B$ Ahmad (PCOSB) for various discussions and useful remarks. We are grateful to PVEP and PCOSB for permission to publish this work.

\section{Công nghệ khai thác nâng cao hệ số thu hồi dầu nặng mỏ cận biên ngoài khơi Việt Nam}

- Vũ Việt Hưng

- Trần Thái Sơn

Công ty điều hành chung Lam Sơn

\section{TÓM TÁT}

Úng dụng công nghệ khai thác dầu nặng đã và đang được phát triển rộng rãi trong hàng thập kỉ qua, nhằm nâng cao hiệu suất thu hồi của loại hydrocarbon khá hóc búa này. Ngoài phuoong pháp nhiệt, công nghệ bơm điện chìm đánh đấu buớc phát triển vuợc bậc trong thu hồi dầu nặng, do tạo ra độ chênh áp lớn giũua via và đáy. Nếu so sánh với phương pháp gas lift truyền thống, thì độ chênh áp lớn do bơm điện chìm tạo ra un việt hơn hẳn.

Bài báo đề cập đến thiết kế công nghệ khai thác cho kế hoạch phát triển mỏ nhằm nâng cao hiệu quả khai thác đặc biệt cho mỏ nhỏ ngoài khoi Việt Nam. Ví dụ nhu ở vùng bồn trũng Cửu Long, với trũ lượng đáng kể dầu khi được phát hiện với chỉ khoảng $20 \mathrm{API}^{0}$ gây không ít ngạc nhiên với các chuyên gia địa chất, tù đó thúc đẩy việc nghiên cưu để tìm ra giải pháp phát triển hiệu quả về mặt kĩ thuật cũng nhu kinh tế cho đối tuợng này. Bài viết đề cập đến một chuỗi các nghiên cứu kĩ thuật tù mô hinh hóa tính khai thác của giếng thăm dò đầu tiên, cho đến thiết kế so bọ thiết bị để phù hợp với đặc tính dầu nặng. Với phuoong thức tiếp cận nhu vậy, bài toán kinh tế cho toàn bộ đời mỏ cũng được nghiên cúu để tối un hóa khai thác. Cuối 
cùng, bài viết lựa chọn công nghệ bơm điện chìm (ESP) là phuoong án tối uu nhất để tăng cuờng hiệu quả khai thác. Qua đó, các thiết bị bề mặt, hệ thống điện cũng nhu bộ thiết bị lòng giếng của bơm chìm kết hợp vói phưong pháp gas lift dụ phòng, công nghệ ngăn cát và bơm hóa phẩm được tích hợ trong toàn bộ hẹ thống nhằm nâng cao khả năng khai thác cũng nhu kéo dài đời mỏ.

Tù khóa: Bơm điện chìm, dầu nặng, thu hồi, kết hợp, dự phòng.

\section{REFERENCES}

[1]. Detailed Well Completion Design, Internal Report, 2012.

[2]. ESP Workshop, the Woodland, 2007.

[3]. Bokor Field ESP Conversion - Completion Selection Report, 2007.
[4]. Kece, M., Heath, R., Web-Ware, A., High Horsepower ESP Application Challenges in Offshore Marginal Fields, SPE EALF, 2008.

[5]. Qahtani, A.A., Electric Submersible Pump (ESP) Selection Optimization: A Reservoir Engineering Outlook, MEALF, 2007. 


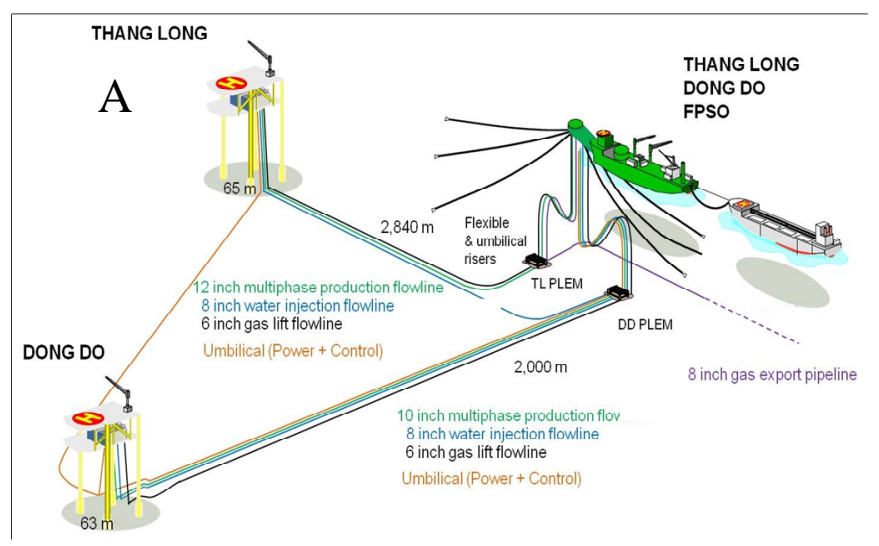

B

Figure 1. Tay Do Field Layout

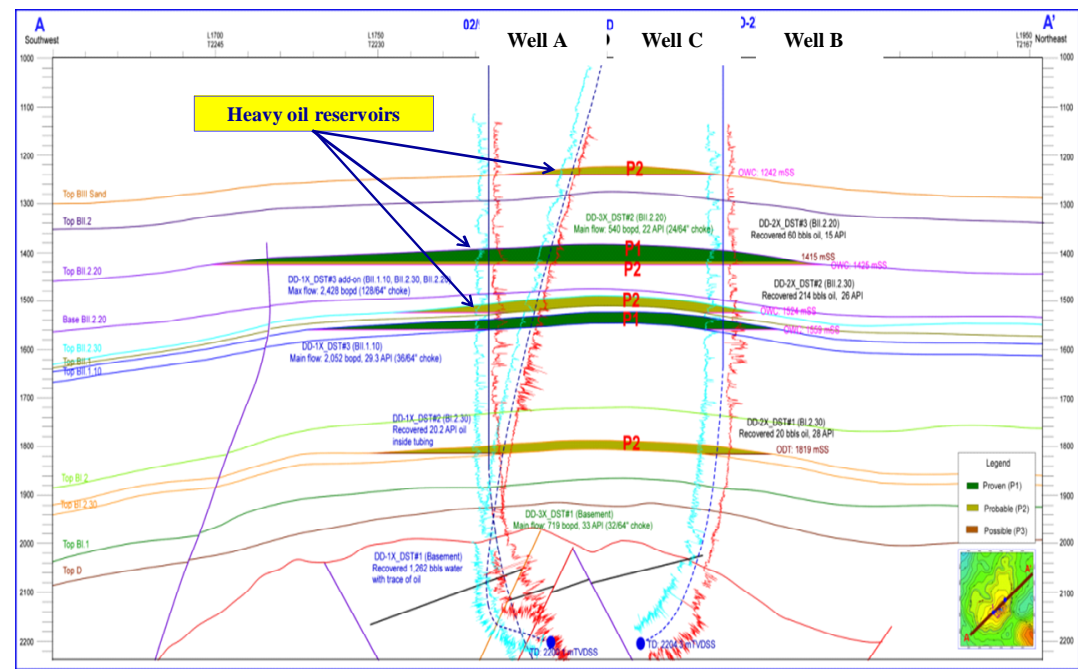

Figure 2. Reservoir Cross Section 


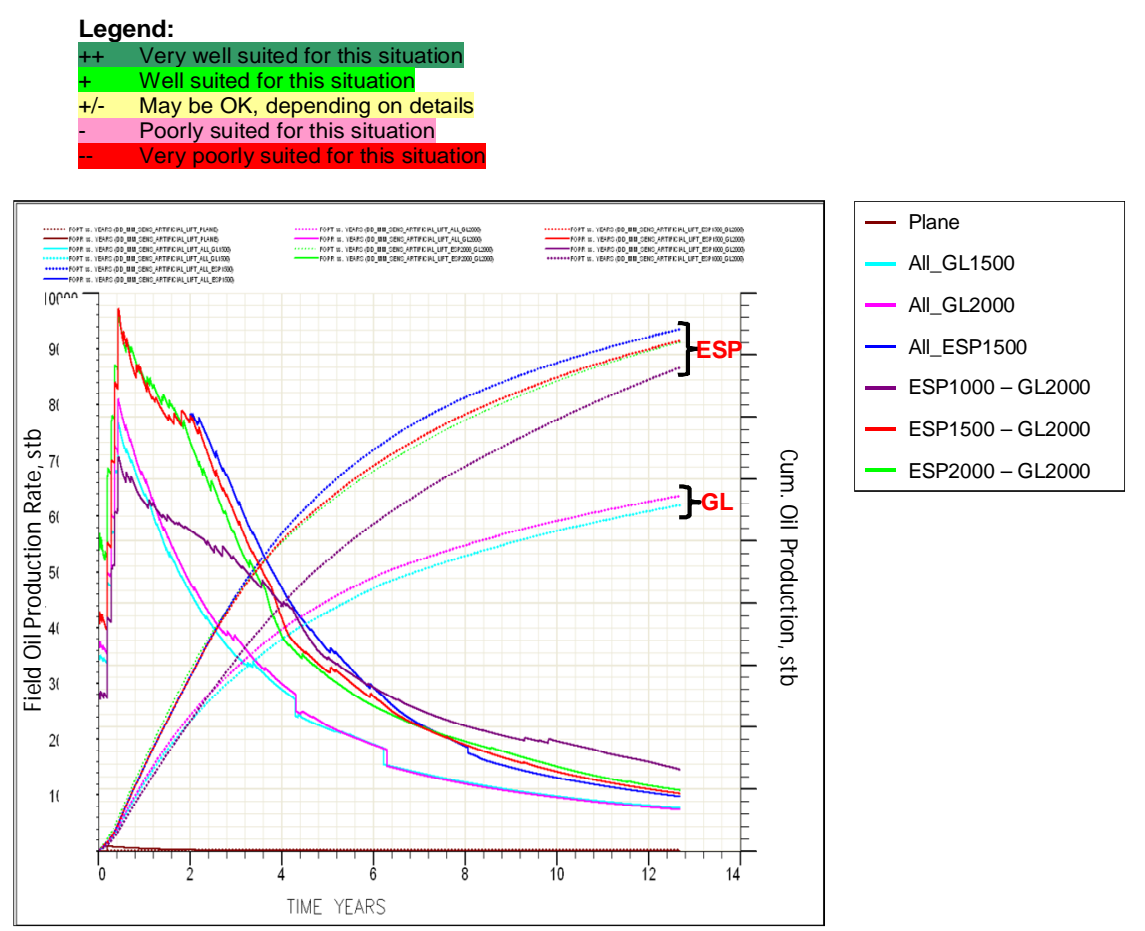

Figure 3. Production Forecast ESP vs. Gas-lift

Table 1. Pertinent Data Input

\begin{tabular}{|l|l|}
\hline Parameter & Value \\
\hline Reservoir Pressure & $1946-2,192 \mathrm{psia}$ \\
\hline Reservoir Temperature & $171-174, \mathrm{deg} . \mathrm{F}$ \\
\hline Well Head Pressure & $250 \mathrm{psia}$ \\
\hline Pump Measured Depth & $4,406-4,987 \mathrm{ft}$ \\
\hline Max OD & 6 in \\
\hline Design Rate & $1500 \mathrm{bbl} / \mathrm{day}$ \\
\hline Gravity (API) & 21 \\
\hline Viscosity & $8.9 \mathrm{cp}$ \\
\hline PI & $3-4 \mathrm{bbl} / \mathrm{psi} / \mathrm{d}$ \\
\hline Total GOR & $5-10 \mathrm{scf} / \mathrm{STB}$ \\
\hline Water Cut & $0 \%-50 \%$ \\
\hline
\end{tabular}


Table 2. Artificial Lift Selection Matrix

\begin{tabular}{|l|l|l|l|l|l|l|}
\hline Characteristic & ESP & PCP & Beam & \multicolumn{1}{l|}{ Hydraulic } & Gas-Lift \\
\hline Well Conditions & + & $+/-$ & $+/-$ & $+/-$ & $+/-$ \\
\hline Deep & + & + & + & + & + \\
\hline Shallow & $+/-$ & $+/-$ & $+/-$ & $+/-$ & + \\
\hline Deviated & - & $+/-$ & $+/-$ & - & $+/-$ \\
\hline Small casing & -- & - & - & - & $+/-$ \\
\hline Dual completion
\end{tabular}

\section{Production Characteristics}

\begin{tabular}{|l|l|l|l|l|l|}
\hline High production rate & ++ & $+/-$ & - & $+/-$ & $+/-$ \\
\hline Low production rate & - & $+/-$ & + & $+/-$ & $+/-$ \\
\hline High bottom-hole pressure & + & + & + & + & ++ \\
\hline Low bottom-hole pressure & $+/-$ & $+/-$ & ++ & $+/-$ & - \\
\hline High GOR & - & $+/-$ & -- & - & ++ \\
\hline Low GOR & + & + & + & + & - \\
\hline Sandy & - & $+/-$ & - & - & $+/-$ \\
\hline Sour & $+/-$ & $+/-$ & $+/-$ & $+/-$ & $+/-$ \\
\hline Viscous & - & $+/-$ & - & - & - \\
\hline Corrosive & - & - & - & - & $+/-$ \\
\hline \hline
\end{tabular}

\begin{tabular}{|l|l|l|l|l|l|}
\hline Location & + & + & + & + & + \\
\hline Onshore & $+/-$ & $+/-$ & - & - & ++ \\
\hline Offshore & $+/-$ & - & - & - & $+/-$ \\
\hline Sub-sea & $+/-$ & $+/-$ & - & - & $+/-$ \\
\hline Developed & $+/-$ & $+/-$ & $+/-$ & - & $+/-$ \\
\hline Remote & & & & \\
\hline \hline
\end{tabular}

\section{Access to Power}

\begin{tabular}{|l|l|l|l|l|l|}
\hline Good electrical power & + & + & + & + & $+/-$ \\
\hline Poor electrical power & - & - & $+/-$ & - & + \\
\hline No access to electrical power & -- & -- & $+/-$ & -- & + \\
\hline
\end{tabular}




\begin{tabular}{|c|c|c|c|c|c|}
\hline \multicolumn{6}{|l|}{ Access to Spare Parts } \\
\hline Ready access to spare parts & + & + & + & + & + \\
\hline Poor access to spare parts & $+/-$ & - & - & - & - \\
\hline \multicolumn{6}{|l|}{ Staff } \\
\hline Trained engineers & + & + & + & + & + \\
\hline No engineers & - & - & $+/-$ & - & $+/-$ \\
\hline Trained operators & + & + & + & + & + \\
\hline Untrained operators & - & - & $+/-$ & - & $+/-$ \\
\hline Good access to service staff & + & + & + & + & + \\
\hline Poor access to service staff & - & - & $+/-$ & - & $+/-$ \\
\hline \multicolumn{6}{|l|}{ Budget Support } \\
\hline Adequate capital budget & + & + & + & + & + \\
\hline Limited capital budget & - & - & $+/-$ & - & $+/-$ \\
\hline Adequate operating budget & + & + & + & + & + \\
\hline Limited operating budget & - & - & $+/-$ & - & $+/-$ \\
\hline
\end{tabular}

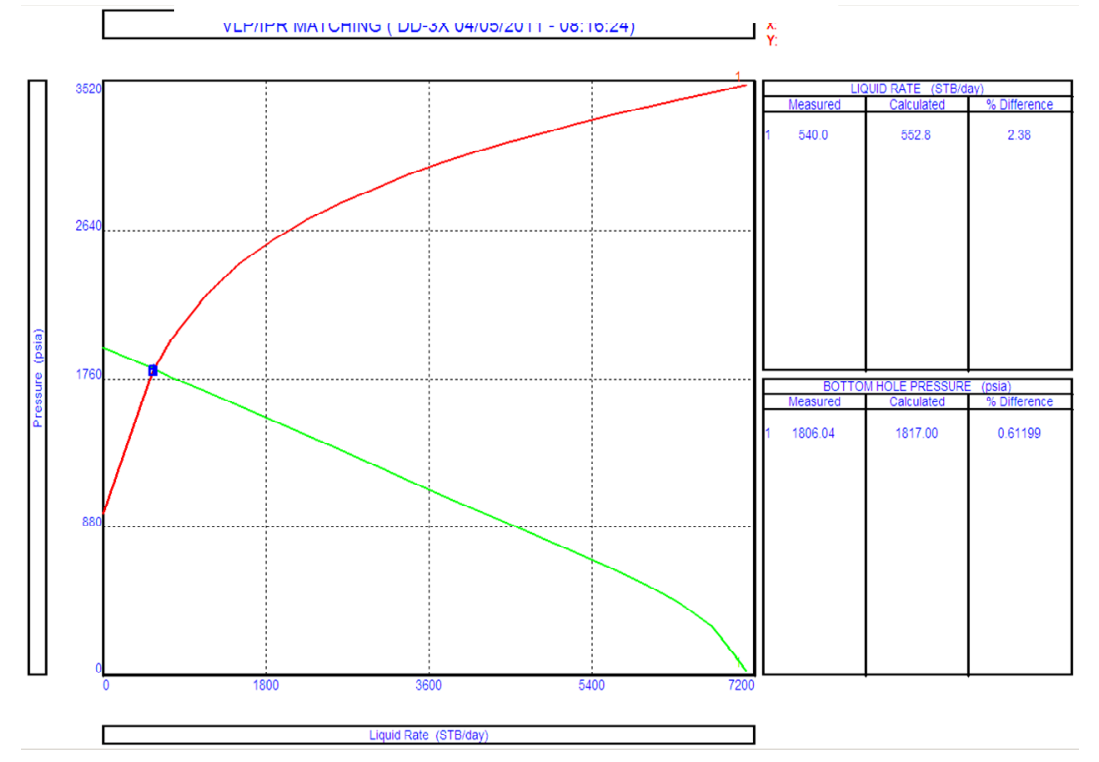

Figure 4. Gas-lift Calibration Point 


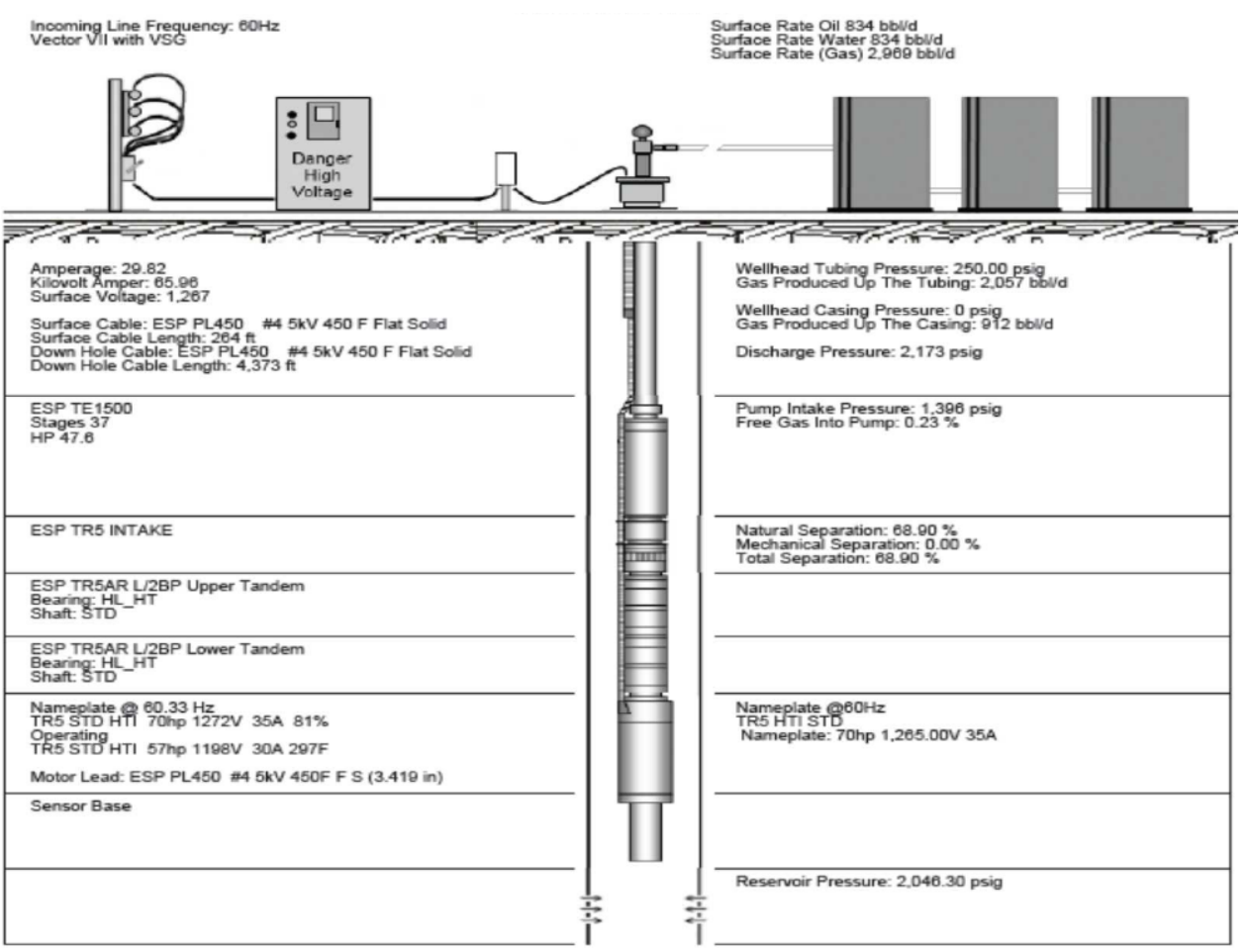

Figure 5. ESP System Configuration

Table 3. ESP Design Summary

\begin{tabular}{|c|c|}
\hline \multicolumn{2}{|c|}{ Well X } \\
\hline Pump & $\begin{array}{c}5.37 \text { inches (800- } \\
2,250 \mathrm{bbl} / \text { day })\end{array}$ \\
\hline No. Stages & 37 \\
\hline Motor & 70 HP $1905 \mathrm{~V} \backslash 23 \mathrm{~A} @ 60 \mathrm{~Hz}$ \\
\hline Intake & No gas separator \\
\hline Shroud & NONE \\
\hline Cable & PL300 5KV LEAD GALV \\
\hline $\begin{array}{c}\text { Cable } \\
\text { Configuration }\end{array}$ & ROUND \\
\hline
\end{tabular}

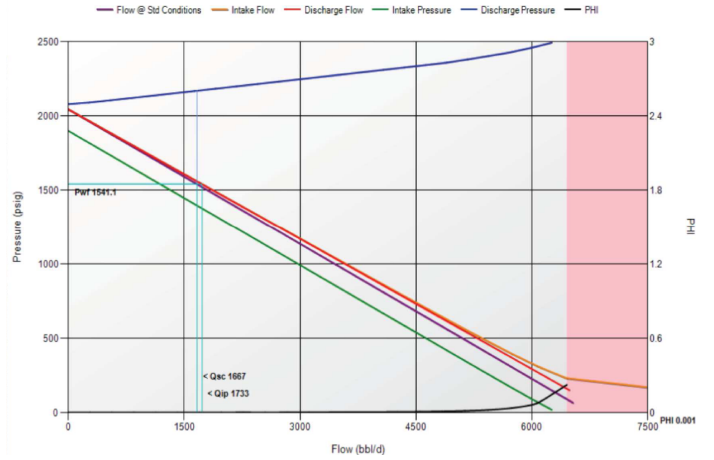

Figure 6. Inflow/Outflow Curve of the Selected Pump 


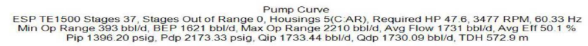

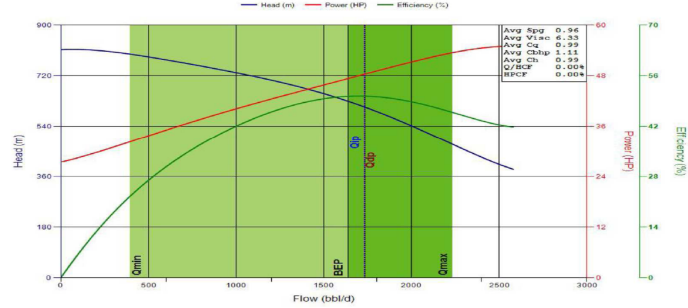

Figure 7. Pump Curve of the Selected Pump
Table 4. ESP Deployment Methods

\begin{tabular}{|c|c|c|}
\hline Description & Advantages & Disadvantages \\
\hline $\begin{array}{l}\text { Conventional jointed pipe } \\
\text { with drilling rig support }\end{array}$ & $\begin{array}{l}\text { - Conventional and simple method } \\
\text { - Gas lift backup } \\
\text { - Low CAPEX }\end{array}$ & $\begin{array}{l}\text { - Long well work-over time } \\
\text { - High work-over cost (OPEX) }\end{array}$ \\
\hline $\begin{array}{l}\text { Conventional jointed pipe } \\
\text { with Hydraulic Work- } \\
\text { over (HWO) Unit support }\end{array}$ & $\begin{array}{l}\text {-A half of drilling rig rate } \\
\text { - Gas lift backup } \\
\text { - Some CAPEX to modify } \\
\text { platform structure }\end{array}$ & $\begin{array}{l}\text { - Longer well shut-in time than } \\
\text { drilling rig } \\
\text { - Increased completion complexity } \\
\text { - Mob/demob issues } \\
\text { - High work over cost (OPEX) }\end{array}$ \\
\hline Coiled Tubing & $\begin{array}{l}\text { - Rigless operation } \\
\text { - Less well shut-in time } \\
\text { - Low workover cost (OPEX) }\end{array}$ & $\begin{array}{l}\text { - High CAPEX } \\
\text { - Well control issue at surface } \\
\text { - No gas lift backup } \\
\text { - Mob/demob issues if run with } \\
\text { large CT size }\end{array}$ \\
\hline
\end{tabular}

Table 5. Preliminary Economic Assessment Result

\begin{tabular}{|c|c|c|c|c|}
\hline & $\begin{array}{c}\text { Conventional } \\
\text { jointed pipe ESP } \\
\text { with drilling rig } \\
\text { support }\end{array}$ & $\begin{array}{c}\text { Conventional jointed } \\
\text { pipe ESP with } \\
\text { Hydraulic Workover } \\
\text { (HWO) Unit support }\end{array}$ & $\begin{array}{l}\text { Coiled Tubing } \\
\text { deploy ESP }\end{array}$ & Remark \\
\hline Waiting time till arrival of WO unit (day/well) & 15 & 45 & 30 & $\begin{array}{l}\text { Analogue to Bokor field with } \\
\text { minor adjustment to cope with } \\
\text { VN market }\end{array}$ \\
\hline W0 time at no production (day/well) & 15 & 25 & 10 & \\
\hline WO unit rental rate (USD/day) & 130,000 & 55,000 & 30,000 & Current VN market \\
\hline Total WO unit rental cost for 6 wells - OPEX (USD) & $11,700,000$ & $8,250,000$ & $1,800,000$ & \\
\hline Number of WO cycles in 10yrs & 3 & 3 & 3 & \\
\hline Total oil production of 6 ESP wells in 10yrs (stb) & $13,942,500$ & $13,465,833$ & $13,823,333$ & Figures from Res. simulation \\
\hline Total undiscounted loss due to WO (USD) & $21,450,000$ & $50,050,000$ & $28,600,000$ & \\
\hline Total number of ESP in 10yrs & 12 & 12 & 12 & 6 new for 1st completion \\
\hline Total cost for 1st ESPs completion - CAPEX (USD) & $1,291,086$ & $1,291,086$ & $2,700,300$ & Analogue to Bokor field \\
\hline Total cost for ESP maintenance in 10yrs - OPEX (USD) & $1,291,086$ & $1,291,086$ & $2,700,300$ & 6 replacements of 3 workovers \\
\hline Cost for surface equipments and completion - CAPEX (USD) & $1,566,072$ & $1,566,072$ & $5,473,584$ & Refer to Bokor Field \\
\hline Total CAPEX (USD) & $2,857,158$ & $4,457,158$ & $8,173,884$ & Including WHP Upgrading \\
\hline Total OPEX (USD) & $12,991,086$ & $9,541,086$ & $4,500,300$ & \\
\hline Total undiscounted net (USD) & $15,848,244$ & $13,998,244$ & $12,674,184$ & \\
\hline Oil Price (USD/stb) & 60 & 60 & 60 & \\
\hline
\end{tabular}




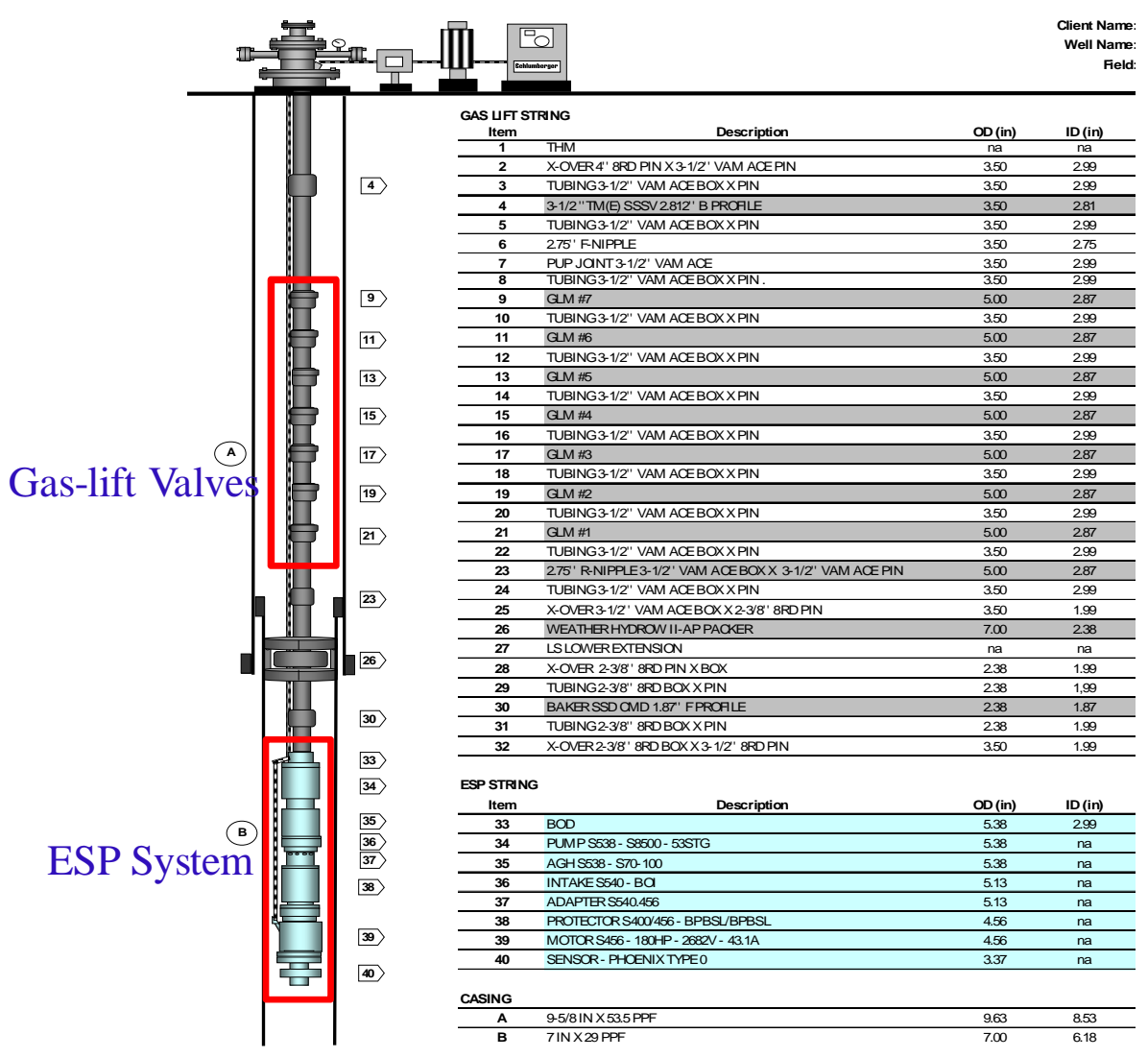

Figure 8. ESP System with Gas-lift backup 